\title{
A patient's diary: episode 14 - Dr Teacher's dream
}

Evening surgery is over. In his consulting room, Dr Teacher relaxes for a few minutes with a favourite Jane Austen novel. But his eyelids are heavy. He sleeps. He dreams ...

Sally Greengage, good-looking, clever and ambitious, with a comfortable flat in a fashionable part of town and a happy disposition seemed to unite some of the best blessings of existence; and had lived nearly 28 years in the world with very little to distress or vex her. Wishing to qualify herself in the medical profession, she had recently engaged herself as apprentice to Mr Gerald Teacher, a reputable local apothecary. She soon proved herself an apt pupil, rapidly acquiring a skillful consultation manner and a good knowledge of medicinal herbs; much admired and respected by her many grateful patients, she seemed to have a brilliant professional future ahead of her.

If she had any fault at all it was perhaps the power of having rather too much her own way and a disposition to think too well of herself. She would sometimes alight on an interesting diagnosis without sufficient resort to the evidence base, or indeed the counsel of her master. She would also delight in giving injudicious advice to the apothecary's female servants concerning their personal lives and matrimonial aspirations. However, these disadvantages of her character, if they can be so described, were at present unperceived by Sally and so did not by any means rank as misfortunes with her.

Now there lived in the pleasant little village of Glanders Magna in the County of Surry, a very civil and respectable gentleman of middle years called Norman Gland. He and his wife, Hilda, had a very pleasant house enclosed before and behind by small, yet well-tended gardens. Although an amiable man, with an enquiring mind and a friendly disposition, it was universally acknowledged that Mr Gland's thoughts were excessively occupied by the state of his health. For many years he had fretted over the condition of his liver and other internal organs; and his conversation revolved almost entirely round the remedies he had sought for them. All manner of herbs were sent for from London; leeches had many times been applied in vain and even the drawing of three of his teeth wherein lay, he was convinced, the source of the disorder, appeased his suffering for only a few days. And now, being once again sorely distressed, he had sent for his favourite apothecary, Mr Teacher, who practised but a few miles away.

So it was that Mr Teacher and Miss Greengage were proceeding in the doctor's new carriage along the country lane which led to Glanders Magna. As the carriage moved along they talked of an affair which had of late been exciting the interest of both of them. There was a young health care assistant in the practice, not above 17 years, who was very taken with $\mathrm{Mr}$ Martin, the local podiatrist and had hopes of an offer of marriage from him. 'Pray, Dr Teacher,' said Sally, 'do not you think that Harriet should aim higher than Mr Martin who is a man of limited education. In truth he is a very agreeable young man but in no way is he Harriet's equal. You may as well know that she shewed me his letter, and I am glad to say that I was able to guide her to pen to refuse his offer. For I have it in mind to make a match for Harriet with $\mathrm{Dr}$ Elton!'

'Oh, Sally' returned her mentor, 'I have always thought your intimacy with Harriet a foolish one, though I have kept my thoughts to myself. But now I perceive that it has been very unfortunate for Harriet. You will puff her up with such ideas about herself that she will lose all chances of matrimony with a man of her station in life. Do not forget the mystery of her parentage which in our society is bound to count against her.'

It was not long before the carriage drew up under the pleasant chestnut trees that sheltered the home of Mr and Mrs Gland. Mrs Gland welcomed them courteously for indeed she was relieved to see them. 'Oh, Miss Greengage, it is so obliging of you to come and bring $\mathrm{Mr}$ Teacher because Norman has been so ill lately, I do not know what to do with him. He lies on the couch in his dressing room, groaning constantly and refusing all food except for a thin gruel which is the only nourishment his poor liver can tolerate. Do tell me, Miss Greengage, have you brought the leeches? Or will you do scarification and cupping today. Please do not draw any more of his teeth or he will never chuse to eat the apple dumplings that I made him, when a week ago I was in high hope of his recovery. Do not you think that the air here might be too full of impurity? We were considering a visit to the sea at South End, but Mr Gland says he is now much too weak. Oh dear, am I talking too much, dear Miss Greengage?'

Sally was tempted to make a tart remark to the effect that Mrs Gland's volubility was entirely within her expectations. Sometimes her youthful high spirits made her tongue run ahead of her kinder sensibilities; and $\mathrm{Mr}$ Teacher had had occasion to remonstrate with her about it, to her considerable shame. This time she restrained herself and merely said, 'not at all, Mrs Gland, you are understandably upset. Now shall you conduct us to your patient?'

So they climbed the stairs and entered the dressing room, where Mr Gland lay groaning. A bowl of gruel lay untouched on the small table by his couch.

'It is good to see you, Teacher,' said the invalid, on perceiving his old friend. 'And your fair apprentice too. But I fear your visit is too late. I fear that the consumption has destroyed my liver entirely and spread to my other vital organs. If only you had a magic glass with which to see inside me you would be amazed at the terrible destruction.' 'Now, now, my dear Gland,' replied the good doctor. 'Pray do not distress yourself in this way. Let me examine this specimen of your urine that I see Mrs Gland has thoughtfully placed on the sideboard for us. Now, I declare, it is perfectly clear and the colour is most satisfactory. If I may say so, your melancholy temperament has again led you to experience a lowering of the spirits as a physical suffering. This is not 


\section{The problem of allergy}

One of the many areas of clinical practice in which GPs are accused of failing to keep up with modern methods is in the management of allergies. It seems that every couple of years some elite medical body documents the woeful state of standards in primary care and insists on the urgent need for more training for GPs as well as demanding the provision of more specialist services.

So when patients ask for a referral for skin tests or other forms of expert investigation and treatment, I duly oblige. It is always something of an anticlimax when they return with a recommendation for a prescription for some combination of an antihistamine, a steroid cream, inhaler or nasal spray, and sodium cromoglycate eye drops. I used to think - 'I could have done that' - in fact, I already had. But now, l'm just grateful that by the time they have discovered the uselessness of patch testing and the limitations of all these medications, their symptoms have usually passed (at least until next time).

It is reassuring to discover, from Mark Jackson's excellent Allergy: the history of a modern malady, that doctors and patients have been engaged in a frustrating waltz around the problem of allergy for more than a century, indeed since 1906 when the Austrian paediatrician Clemens von Pirquet coined the term. Like most such neologisms, this one was not well received by his peers and it took a while to catch on.

Yet in time it proved a potent and enduring metaphor for the 'pathologies of progress' in the 20th century, its associated conditions expressing a 'symbolic aversion to the diverse horrors of modern life'.' Jackson notes the pioneering allergists' difficulties in establishing a firm scientific foundation for their emergent clinical speciality.

Nor could science resolve the longrunning turf war between mainstream allergists who insisted on a strict definition of allergic conditions in terms of hypersensitivity reactions and clinical ecologists who sought to include a wide range of disorders attributed to diverse environmental factors and associated with a vast range of non-specific symptoms.
This battle was once characterised by the paediatric immunologist John Soothill as a conflict between 'the blimps', predominantly respectable physicians, and 'the nuts', sometimes renegade doctors or psychiatrists, joined by a range of alternative therapists and nutritionists. For the blimps, allergy meant simply hay fever, asthma, urticaria, and eczema, for the nuts, however, allergy signified the full diversity of human responses to the toxic hazards of modern life.

Over the past two decades a growing environmentalist consciousness has provided a ready resonance for the notion of an epidemic of allergic disorders resulting from atmospheric pollution and from chemicals in the workplace, in the home, and in foods and drugs. The blimps have baulked at nutty notions such as 'multiple chemical sensitivity', and have rejected many nutty (though lucrative) tests. However, they have pragmatically relabelled 'food allergy' as 'food intolerance' and have entered the flourishing market in elimination diets and nutritional supplements.

While the blimps have always been quick to accuse the nuts of quackery and profiteering, ever since Big Pharma (in the shape of Parke Davis \& Co) financed Sir Almoth Wright's pioneering Department of Therapeutic Inoculation at St Mary's in the 1920s, the boundaries in allergy between science and pseudoscience, and between evidence-based practice and commercially-driven practice, have always been blurred.

It is heartening to see that, 20 years after GPs were effectively banned from giving courses of desensitising injections for hay fever after a series of anaphylactic fatalities, immunotherapy is now making a comeback (at least in hospital outpatient departments). A century on, allergy has come full circle. As Jackson observes, 'perhaps more than any other condition, allergy embodies the biological, political, and spiritual challenges faced by inhabitants of the post-modern world'.

\section{REFERENCES}

1. Jackson M. Allergy: the history of a modern malady. London: Reaktion, 2006.

DOI: 10.3399/bjgp08X277159 